\title{
'Apostles of Continence': Doctors and the Doctrine of Sexual Necessity in Progressive-Era America
}

\author{
TIMOTHY VERHOEVEN * \\ School of Philosophical, Historical and International Studies, Monash University, \\ W609, 20 Chancellor's Walk, Clayton, Victoria 3800, Australia
}

\begin{abstract}
In the first decades of the twentieth century, a group of doctors under the banner of the social hygiene movement set out on what seemed an improbable mission: to convince American men that they did not need sex. This was in part a response to venereal disease. Persuading young men to adopt the standard of sexual discipline demanded of women was the key to preserving the health of the nation from the ravages of syphilis and gonorrhoea. But their campaign ran up against the doctrine of male sexual necessity, a doctrine well established in medical thought and an article of faith for many patients. Initially, social hygienists succeeded in rallying much of the medical community. But this success was followed by a series of setbacks. Significant dissent remained within the profession. Even more alarmingly, behavioural studies proved that many men simply were not listening. The attempt to repudiate the doctrine of male sexual necessity showed the ambition of Progressive-era doctors, but also their powerlessness in the face of entrenched beliefs about the linkage in men between sex, health and success.
\end{abstract}

Keywords: Abstinence, Sexuality, Masculinity, Social Hygiene, Venereal Disease, Progressive Era

\section{Introduction}

At the beginning of the twentieth century, a group of doctors mobilised against an epidemic of venereal disease that seemed to be sweeping the United States. The scale of the threat was set out in stark terms by the New York physician Prince A. Morrow. Though admitting that precise figures were impossible to obtain, Morrow estimated that anywhere from five to eighteen per cent of the adult male population carried the syphilis bacteria. In the case of gonorrhoea, the infection rate was no less than seventy-five per cent. ${ }^{1}$ As Morrow emphasised, this was both an individual and a social scourge. Infected men were imperilling not only their own health but also that of their wives and unborn children;

* Email address for correspondence: tim.verhoeven@monash.edu

I would like to thank the members of my reading group in the history programme for their help and suggestions, as well as the anonymous reviewers for the journal. Many thanks as well to the staff at the National Library of Medicine, Bethesda, Maryland.

${ }^{1}$ Prince A. Morrow, Social Diseases and Marriage: Social Prophylaxis (New York: Lea Brothers, 1904), 25. 
there was more venereal disease among virtuous wives, Morrow warned, than professional prostitutes. $^{2}$ If left unchecked, this epidemic would sap the health and prosperity of the nation for generations to come.

In response, doctors and sanitarians organised into the social hygiene movement. Their program was captured in the charter of the American Society for Sanitary and Moral Prophylaxis (ASSMP), an organisation which Morrow founded in February 1905. Social hygienists' first concern was education. For too long, Morrow declared, educators as well as doctors had avoided a frank public discussion of sexual hygiene for fear of offending moral sensibilities. ${ }^{3}$ But most of all, doctors had been too timid in tackling the sexual double standard which tolerated male promiscuity while punishing women for transgressing the sexual code. The venereal peril would never be defeated until men were held to the standards of chastity and discipline demanded of women. ${ }^{4}$ Young men in particular should be taught, Morrow announced, that 'the reproductive function is given for a higher purpose than mere sensual gratification' and that it was 'susceptible of control, discipline and proper direction'. 5 It was time for men to embrace a new ethos of sexual discipline which the hygienists most commonly referred to as continence.

Here, Morrow and his colleagues ran up against the doctrine of male sexual necessity. This doctrine encompassed two strands. The first was that prolonged sexual abstinence would give rise to a series of physical and psychological disorders. The second was that regular intercourse was necessary for a man to retain his vigour and his effectiveness. Both ideas had a long medical pedigree, and both were firmly entrenched. As Morrow conceded, the belief that sex was essential to health was 'almost universally prevalent among young men'. ${ }^{6}$ But until this was debunked, the campaign to defeat venereal disease was sure to fail. As an ASSMP pamphlet aimed at college students noted, the doctrine was 'one of the most powerful stimulants to sexual debauch'. Men would continue to engage in illicit sex, and venereal disease would continue to flourish, unless the doctrine of sexual necessity was shown to be a 'physiologic fallacy'. ${ }^{7}$ It was time, according to William Osler, a founding professor of Johns Hopkins Hospital and for decades one of the most respected clinicians in the nation, that doctors stopped winking at the promiscuous behaviour of their male patients and embraced their calling as 'the apostles of continence'. ${ }^{8}$

This article investigates the manner in which Progressive-era doctors sought to prove what seemed to many men an outlandish idea, that sex was not necessary for health or efficiency. Scholarship on the history of venereal disease has noted the focus on male continence. In his landmark work, Allan M. Brandt described the manner in which

\footnotetext{
2 Prince A. Morrow, 'A Plea for the Organization of a "Society of Sanitary and Moral Prophylaxis", Medical News, 84 (1904), 1075.

${ }^{3}$ On sex education in this era, see Jeffrey P. Moran, Teaching Sex: The Shaping of Adolescence in the 20th Century (Cambridge: Harvard University Press, 2000); Robin E. Jensen, Dirty Words: The Rhetoric of Public Sex Education, 1870-1924 (Urbana: University of Illinois Press, 2010).

${ }^{4}$ On reformers opposed to the sexual double-standard, see Christina Simmons, Making Marriage Modern: Women's Sexuality from the Progressive Era to World War II (New York: Oxford University Press, 2009), 33; James H. Adams, Urban Reform and Sexual Vice in Progressive-Era Philadelphia: The Faithful and the Fallen (Lanham: Lexington Books, 2015), 18-19.

${ }^{5}$ Prince A. Morrow, 'The Society of Sanitary and Moral Prophylaxis: Its Objects and Aims', Transactions of the American Society for Sanitary and Moral Prophylaxis, 1 (1906), 30.

${ }^{6}$ Ibid., 30.

${ }^{7}$ Health and the Hygiene of Sex for College Students, Educational Pamphlet No. 6 (New York: American Society of Sanitary and Moral Prophylaxis, 1911), 12.

${ }^{8}$ William Osler, 'History of medicine', in Frederick Converse Beach (ed.), The Americana: A Universal Reference Library, vol. 13 (1903), no page number.
} 
continence became the 'hallmark of all sexual prescription' and sketched some of the medical arguments deployed in its support. ${ }^{9}$ Several studies focus on the most ambitious phase of this Progressive campaign, the effort to make the American Expeditionary Force in France into a bastion of sexual purity. ${ }^{10}$ But while building on existing scholarship, this study goes further in several ways. First, it offers a thorough and focussed investigation of the arguments deployed by doctors as they sought to refute the doctrine of sexual necessity. These arguments were varied, ranging from analogies with other organs to theories grounded in the emerging science of endocrinology. But whatever their chosen method of attack, social hygienists felt impelled to go beyond moral exhortation if they were to persuade young men to change their behaviour. This view was put succinctly by Max Huhner, chief of the clinic of the genito-urinary department at Mount Sinai Hospital and the inventor of a test for male sterility. Religious ministers, as Huhner wrote, could 'preach chastity and purity from morning till night', but if doctors stated that coitus was necessary, patients would 'throw aside the teachings of the clergyman' in an instant. ${ }^{11}$ In an age which venerated technical expertise and scientific progress, only arguments grounded in physiology would ultimately prove persuasive.

Second, this article incorporates both the significant level of medical dissent as well as the evidence, often gathered by doctors themselves, of the impact of their crusade. Much of the scholarship on the Progressive-era campaign against venereal disease presents a united front of doctors rallying behind the call for male continence and effecting a sea change in public attitudes and behaviour. John C. Burnham once wrote of a revolution in attitudes towards sex; more recently, David J. Pivar has charted the destruction of the idea of male sexual necessity. ${ }^{12}$ Such arguments are only partially accurate when applied to the medical profession, and appear even less convincing when extended to public attitudes and behaviour. Dissenters within the profession attacked the continence message as unscientific, vague and unhelpful. At the same time, the emergence of Freudian theory opened up a new and potentially very damaging line of resistance. Making matters worse, rudimentary attempts to measure the impact of the continence crusade produced alarming results. An investigation at the State University of Kentucky in 1915 suggested that young men were not listening. The ultimate test would be the First World War. With the power and resources of a government at war on their side, and a pool of men removed from the temptations of city life, social hygienists saw an unparalleled opportunity to refute once and for all the doctrine of sexual necessity. Again, however, the evidence for a transformation in either attitudes or behaviour was scanty at best.

${ }^{9}$ Allan M. Brandt, No Magic Bullet: A Social History of Venereal Disease in the United States since 1880 (New York: Oxford University Press, 1987), 26-31; Bryan Strong, 'Ideas of the Early Sex Education Movement in America, 1890-1920', History of Education Quarterly 12, 2 (1972), 129-61; Mark Thomas Connelly, The Response to Prostitution in the Progressive Era (Chapel Hill: University of North Carolina Press, 1980), 77 8. Other references to the doctrine of sexual necessity can be found in Simmons, op. cit. (note 4), 36; John D'Emilio and Estelle B. Freedman, Intimate Matters: A History of Sexuality in America (New York: Harper and Row, 1989), 206.

${ }^{10}$ Nancy K. Bristow, Making Men Moral: Social Engineering During the Great War (New York : New York University Press, 1996); Brandt, No Magic Bullet, 52-121; Christopher Capozzola, Uncle Sam Wants You: World War I and the Making of the Modern American Citizen (New York: Oxford University Press, 2008), 132-6.

${ }^{11}$ Max Huhner, A Practical Treatise on Disorders of the Sexual Function in the Male and Female (Philadelphia: F.A. Davis, 1916), 260.

12 John C. Burnham, 'The Progressive Era Revolution in American Attitudes Towards Sex', Journal of American History 59, 4 (1973), 885-908; David J. Pivar, Purity and Hygiene: Women, Prostitution, and the 'American Plan', 1900-30 (Westport: Greenwood, 2002), 3. 
A further aim of this article is to embed this American debate in a wider transatlantic context. The protagonists oscillated between a belief in national uniqueness and a willingness to look abroad for information and support. Many assumed that, whatever their failings, American men were far more wholesome than continental Europeans, an assumption which was confirmed by the wartime experience. As social hygienists struggled to maintain sexual discipline amongst the troops, they were confronted with what appeared a disdainful response on the part of French authorities. Yet alongside this awareness of national difference was an openness to theories and approaches which came from Europe, as well as a connection to similar endeavours abroad. To cite one example, Morrow was inspired to found the ASSMP by his participation in the Second International Conference on the Prophylaxis of Venereal Diseases and Syphilis, which was held in Brussels in November 1902. The medical case for continence, then, presents an interesting example of the interplay between the national and the transnational in a social reform movement.

A final concern of this study is masculinity. The fixation with continence might be seen as a desperate response to the spread of venereal disease on the part of doctors who, at least until the release of Salvarsan in 1910, lacked an effective treatment. ${ }^{13}$ But a far more decisive factor in driving their crusade was the growing panic over the impact of civilisation on the male body. Modern man was caught in what Gail Bederman has termed the 'neurasthenic paradox'. ${ }^{14}$ More than a century of advances in knowledge and in social organisation had created the conditions in which middle-class men could attain an unprecedented mastery over the sexual instinct. Their self-restraint, in turn, was both a motor of further progress and a mark of superiority over primitive races and classes. But, as doctors and reformers were beginning to understand, progress had its costs. The frenetic pace of urban life, combined with the shift of more and more men into sedentary and intellectual occupations, was draining men of their virility, leaving them in the state of nervous exhaustion which George M. Beard termed neurasthenia. Civilisation had taught men to master their primitive urges; over-civilisation, in the term that was coined in the early twentieth century, was turning them into flabby-bodied weaklings. The cure was a strong dose of the primitive. By the turn of the century, physicians were just one group encouraging men to throw themselves into fortifying activities - sports, bodybuilding, hunting, camping - which would instil toughness and vigour, and counteract the emasculating effects of civilisation. ${ }^{15}$

At first glance, urging young men to abstain from sex seems a curious response to the problem of over-civilisation. The heightened call for restraint jarred in an era which more and more celebrated male power and aggression. At the same time, the structural conditions of modern life, notably the ever-lengthening delay in marriage, made the achievement of such restraint extremely difficult. Yet social hygienists saw a way out of this dilemma. Far from advising young men to ignore or smother their sexual instinct, doctors urged them instead to battle against it. Here was the testing ground which so many

13 John Parascandola, A History of Syphilis in America (Westport: Praeger, 2008), 22.

${ }^{14}$ Gail Bederman, Manliness and Civilization: A Cultural History of Gender and Race in the United States, 1880-1917 (Chicago: University of Chicago Press, 1995).

15 John F. Kasson, Houdini, Tarzan, and the Perfect Man: The White Male Body and the Challenge of Modernity in America (New York: Hill and Wang, 2001); Clifford Putney, Muscular Christianity: Manhood and Sports in Protestant America, 1880-1920 (Cambridge: Harvard University Press, 2001); John Pettegrew, Brutes in Suits: Male Sensibility in America, 1890-1920 (Baltimore: Johns Hopkins University Press, 2007); E. Anthony Rotundo, American Manhood: Transformations in Masculinity from the Revolution to the Modern Era (New York: Basic Books, 1993). 
men seemed to yearn for. Rather than braving the wilderness or vanquishing an opponent on the sports field, men could enter perhaps the fiercest combat of all, that against their own desires. This was how the male body could be steeled and disciplined. Gender, then, was critical. The apostles of continence could boast that the laws of physiology were on their side. But as we shall see, they slipped very easily into a language of true masculinity that was infused with wider concerns about the character of young men and the stability of the male body in an increasingly urban and affluent society.

\section{The Case against Male Sexual Necessity}

In teaching young men that sex was not necessary, Progressive-era doctors were challenging a widely-held conviction. There was, Morrow lamented, an 'almost universal infection of the minds of young men' that sex was essential to health and success, a belief that was the primary cause of 'masculine immorality'. ${ }^{16}$ Even more alarmingly, this belief came from doctors. We are familiar with the Victorian-era diatribes against sexual indulgence. But grim descriptions of the harm caused by excessive coitus were always balanced by similarly stark warnings of the physical and mental disorders brought about by prolonged sexual abstinence. The most common was impotence, and the aetiology was easy to follow. The sexual organs were no different to muscles. If not used, they tended to atrophy; even worse, the effects might prove irreversible. For proof, American physicians looked across the Atlantic. The Englishman John Laws Milton was a member of the Royal College of Surgeons and an expert on venereal disease. In his On the Pathology and Treatment of Gonorrhoea and Spermatorrhoea, a work which was published and widely read in the United States, Milton laid down a general law that 'a structure, a muscle for instance, if never exercised, will waste and become impotent'. Whilst the genital organs were used more intermittently than muscles, observations of his patients showed that the same rule applied. One, a 26-year-old virgin, was distressed to find that the vigour of his erections had been diminishing for more than a year, to the point that he could no longer muster anything like, in Milton's terms, a 'proper erection'. ${ }^{17}$

In such cases, the best cure was a quick marriage. But even this might not reverse the damage. Milton noted the possibility that the sexual organs would never 'regain their natural tone'. For one patient, even thirteen years of marriage had not worked to restore the squandered sexual power. ${ }^{18}$ In a work first published in 1883, but which was reprinted as late as 1907, the American physician Joseph W. Howe agreed with Milton's observations. It was rare, he argued, that a man would be able to remain absolutely continent into his late twenties and then enjoy normal conjugal relations. For this reason, it was imperative that a healthy man be married by the age of twenty-four. ${ }^{19}$ More controversially, Howe conceded that bachelors were likely to seek premarital sex as an easier option. Once they learned that 'intercourse was one of the essentials to perfect health', he acknowledged, the 'large majority indulge their natural instincts without the formality of marriage'. ${ }^{20}$ There was little that a physician could do to stop them.

16 Prince A. Morrow, 'Sanitary and Moral Prophylaxis', Boston Medical and Surgical Journal 154, 24 (1906), 676.

17 John Laws Milton, On the Pathology and Treatment of Gonorrhoea and Spermatorrhoea (New York: William Wood and Company, 1887), 356.

18 Ibid., 357.

${ }^{19}$ Joseph W. Howe, Excessive Venery, Masturbation and Continence: The Etiology, Pathology and Treatment of the Diseases Resulting from Venereal Excesses, Masturbation and Continence (New York: E.B. Treat, 1907), 184.

${ }^{20}$ Ibid., 200. 
But impotence was not the only problem. Within the long-standing 'evacuation' model of male sexual physiology, prolonged abstinence in a virile man became a highly dangerous practice. Many physicians argued that the testes continued to produce seminal material in the absence of erotic stimulation. If this material did not find an outlet, a state of accumulation or blockage would ensue. A man in such a state was prey to a host of sexual disorders. He might be plagued by seminal emissions. These could be voluntary, as in the case of masturbation, or involuntary, in the case of the pathology known as spermatorrhoea. The upshot of both was moral shame and physical decline. ${ }^{21}$ In extreme cases, he might find himself in the grip of satyriasis, a condition of excessive sexual desire in men. Here the state of 'genital irritation' triggered by the accumulation produced a level of desire so great that it overpowered the mind. At this point, physicians warned, a man would cast aside all respect for law, morality and decency and attack the first woman or child that crossed his path in a desperate effort to find sexual relief. ${ }^{22}$

The first task for the apostles of continence, then, was to dismantle this body of medical scholarship. The key point of attack was the linkage between continence and impotence. Edward. L. Keyes Jr held a series of prestigious posts at hospitals in New York and lectured on urology at Georgetown University. In 1915, he became president of the American Urological Association. An early and enthusiastic member of the social hygiene movement, Keyes wrote at length about the physiological falsity of sexual necessity. He began by stating that it was unscientific to assume that bodily organs lost their strength if not exercised regularly. Here he cited the example of the tear duct. A man would retain the power to cry, he asserted, even if his eyes had remained dry for fifty years. The sexual organs were akin to the tear duct in that they did not require constant usage to remain functional. ${ }^{23}$

Like their opponents, the continence crusaders looked across the Atlantic for support. In a paper to the American Academy of Medicine, William Alexander Newman Dorland, editor of one of the most widely used medical dictionaries, drew on several English authorities to refute the theory that the sexual organs atrophied in the absence of intercourse. One was William Acton, perhaps the most influential Victorian authority on sexual behaviour. Acton, as Dorland noted, had never seen a case of shrinkage of the testes produced by continence. A further authority was the English surgeon Thomas Bryant, author of the widely published Manual for the Practice of Surgery. Bryant was unequivocal: the testis 'does not waste or atrophy for want of use'. Here was overwhelming proof, Dorland concluded, that the only 'quasi-legitimate plea for illicit intercourse' had in fact no scientific legitimacy at all. ${ }^{24}$

What, though, of the link between continence, masturbation and spermatorrhoea? Here the apostles of continence argued that emissions, if moderate in frequency and accompanied by wholesome living, were a harmless safety valve. When compared to the risks of illicit intercourse, even masturbation, that secret sin which had so haunted

${ }^{21}$ Ellen Bayuk Rosenman, 'Body Doubles: The Spermatorrhea Panic', Journal of the History of Sexuality 12, 3 (2003), 365-99; Robert Darby, 'Pathologizing Male Sexuality: Lallemand, Spermatorrhea, and the Rise of Circumcision', Journal of the History of Medicine and Allied Sciences 60, 3 (2005), 283-319; Elizabeth Stephens, 'Pathologizing Leaky Male Bodies: Spermatorrhea in Nineteenth-Century British Medicine and Popular Anatomical Museums', Journal of the History of Sexuality 17, 3 (2008), 421-38.

22 Timothy Verhoeven, 'Pathologizing Male Desire: Satyriasis, Masculinity and Modern Civilization at the Fin de Siècle', Journal of the History of Sexuality 24, 1 (2015), 25-45.

${ }^{23}$ Edward L. Keyes Jr., 'The Sexual Necessity', Medical News, 87 (1905), 74.

${ }^{24}$ W. A. Newman Dorland, 'The Social Aspect of Gonococcal Infection of the Innocent', Bulletin of the American Academy of Medicine, 11 (1910), 470. 
the Victorian medical imagination, appeared a minor failing. The pure-minded, Edward L. Keyes Jr argued, would not be impaired by such 'occasional lapses from integrity', and as long as their minds and bodies were kept active in 'manly exercises and outdoor sports', there was no danger at all. ${ }^{25}$ Similarly, doctors began to downplay the effects of involuntary emissions. Max J. Exner was a public health officer with the YMCA and a prominent member of the social hygiene movement. In one of his many works of sex education, Exner reassured young men that emissions were a natural bodily mechanism. Nature, he argued, had 'carefully provided' for a process through which the spermatozoa could be 'to some extent liberated'. ${ }^{26}$ When occurring infrequently, there was no lasting physical or mental harm and no need for shame.

The problem with these arguments was that they remained stuck within the conceptual framework of accumulation and release. As long as that model of male sexuality retained its popularity, the arguments for continence were unlikely to advance very far. Granville Stanley Hall was a psychologist, educator and author of a pioneering and influential study of adolescence. He lashed out at continental European doctors who were responsible, in his view, for popularising the evacuation model. A particular target was the Frenchman Charles Féré, chief medical officer of the Bicêtre Hospital. In his The Evolution and Dissolution of the Sexual Instinct, Féré characterised sexual desire as 'a kind of need of evacuation'. This unfortunate phrase, Hall argued, 'strikes hands with the idea so current among youth of to-day ... that the glands must be discharged and their secretion eliminated from the system'. It was, in other words, a license for promiscuity which was both 'devastating morally' and responsible for creating 'an enormously exaggerated idea of the difficulties of continence'. ${ }^{27}$ Proving that sex was not necessary required the elaboration of an entirely different model.

Hall may have traced the root of the problem to French doctors, but the solution also came from the continent in the form of the emerging science of endocrinology. In the last decades of the nineteenth century, clinicians and pathologists conducted a number of experiments in order to establish the role of what were termed 'internal secretions' or 'organ extracts'. Though much of this early research centred on adrenal and thyroid extracts, the work of the Frenchman Charles Édouard Brown-Séquard drew attention to a substance produced by the testes. As early as 1869, Brown-Séquard had speculated that injecting sperm into the veins of old men might slow the effects of ageing. Twenty years later, he argued to the Society of Biology in Paris that the testes contained an active, invigorating substance which stimulated physical as well as mental growth, and which might be used as a rejuvenating agent. ${ }^{28}$ So confident was Brown-Séquard in this theory that he injected himself with an extract of ground dog testicle. Though there was much scepticism about any 'elixir of youth', research continued along two tracks: observations of the effects of castration on animals and humans, and transplants of material.

25 Keyes, op. cit. (note 23), 74.

${ }^{26}$ Max J. Exner, The Physician's Answer: Medical Authority and Prevailing Misconceptions about Sex (New York: Association Press, 1913), 13.

${ }^{27}$ G. Stanley Hall, Adolescence: Its Psychology and Its Relations to Physiology, Anthropology, Sociology, Sex, Crime, Religion and Education, vol. 2 (New York: D. Appleton, 1904), 140. For Féré, see Charles Féré, The Evolution and Dissolution of the Sexual Instinct (Paris: Charles Carrington, 1904), 8. In general, however, Féré argued that continence was harmless.

${ }^{28}$ Charles Édouard Brown-Séquard, 'Expérience démontrant la puissance dynamogénique chez l'homme d'un liquide extrait de testicules d'animaux', Archives de Physiologie Normale et Pathologique, 5, 1 (1889), 651-58. See Michael J. Aminoff, Brown-Sequard: An Improbable Genius Who Transformed Medicine (New York: Oxford University Press, 2010). 
A widely cited French study of eunuchs proved that secondary sexual characteristics did not develop in men who had been castrated before puberty. ${ }^{29}$ A similar lack of physical development was observed in castrated animals. Further experiments seemed to prove that transplants of what was termed 'testicular extract' could reverse these effects. One German histologist, Moritz Nussbaum, claimed to have demonstrated the decisive role of internal secretions by grafting testicular material on to a castrated frog. Very quickly, he reported, the castrated frog developed the same secondary sexual characteristics displayed by a normal frog. ${ }^{30}$

This research was important because it gave a modern scientific basis to the age-old association between semen and male vitality. Since the Classical era, medical authorities had identified semen as an energising fluid which could be harnessed by the body. By the early twentieth century, this belief in the rejuvenating power of semen had been largely discredited. But proponents of continence could now argue that the retention of the mysterious internal secretions had the same powerful and revitalising effect. According to one ASSMP pamphlet, the normal male did not reach full sexual maturity until the age of twenty. Any sexual activity before then would rob the adolescent body of the benefits of secretions, leading it to become stunted and feeble. Sexual purity would ensure that the adolescent emerged as a strong, determined and robust man. ${ }^{31}$

Physiologists were a long way from understanding the operation of this invisible substance, which they called 'spermin', and the complexity of the science could not be easily conveyed to a lay audience. Fortunately, the proof that sexual discipline was invigorating rather than enfeebling could be seen before one's eyes. William H. Howell, president of the American Physiological Association and dean of the Johns Hopkins Medical School, looked to Catholic priests. He was convinced, Howell wrote, that despite a small number of scandals, the vast majority of priests remained faithful to their vow of celibacy. These men embodied the physiological benefits of mastering desire. Their ability to 'triumph over this primitive instinct' was the basis of their ascent to a 'higher level of excellence, physical, moral and intellectual'. ${ }^{32}$ The celibacy of the priest was life-long, but the laity could benefit from shorter periods of abstinence. After all, it was common knowledge that scholars, athletes and artists performed at their best while remaining strictly chaste.

Here the apostles of continence moved on to the terrain of gender. On one level, their arguments drew heavily on notions of true womanhood. The man who doubted the feasibility of continence need only look, Max J. Exner argued, to the women around him for inspiration. Society granted no easy concession to female promiscuity, and the vast majority of women were satisfied that it did not. Women controlled their sexual instincts; the burden was now on men to follow their lead. ${ }^{33}$ To emphasise the point, doctors raised the shocking idea of a doctrine of female sexual necessity. Imagine, Edward L. Keyes Jr.

\footnotetext{
${ }^{29}$ Hikmet (de Constantinople) and Félix Regnault, 'Les Eunuques de Constantinople', Bulletins et Mémoires de la Société d'Anthropologie de Paris, 5, 2 (1901), 234-40.

${ }^{30}$ Moritz Nussbaum, 'Innere Sekretion und Nerveneinfluss', in Fr. Merkel and R. Bonnet (eds), Anatomische Hefte Referate und Beiträge zur Anatomie und Entwicklungsgeschichte (Wiesbaden: J.F. Bergmann, 1905), 3989. The state of this research was set out to an American audience by Francis H. A. Marshall in his The Physiology of Reproduction (New York: Longmans, Green, 1910), 303-314.

31 'Health and the Hygiene of Sex', op cit. (note 7), 6.

${ }^{32}$ William H. Howell and Edward L. Keyes Jr., The Sexual Necessity (New York: Society of Sanitary and Moral Prophylaxis, 1913), 11-12.

${ }^{33}$ Exner, op. cit., (note 26), 18.
} 
asked his male readers, that your daughter is now thirty years old and still unmarried. You notice that she is beginning to suffer from a series of ailments caused by the fact that she has never given birth. Would you advise her to seek a remedy to her unnatural state through sex outside of marriage? The answer for Keyes was obvious - the true father would rather see his daughter suffer, even die, than allow her to 'debase herself and sully her vestal purity'. ${ }^{34}$ Fathers, Keyes concluded, should hold their sons to the same rigorous standard.

The fact that Keyes identified the ailment of this hypothetical daughter as what he termed 'balked maternity' rather than sexual frustration is revealing. Hygienists could never shake the assumption that women experienced less sexual desire than men, and that, as a consequence, they found the continent life far easier to bear. Maternity more than desire was the key to female sexuality; as opposed to men, the sex impulse in women was, in Exner's terms, 'comparatively quiescent' ${ }^{35}$ But if men had to fight harder, they should see this as an opportunity rather than an obstacle. The continent man steeled himself to resist temptation, embraced the discipline of remaining chaste, and scorned any easy indulgence in sensual pleasure. He might indeed, as Exner argued, be troubled with minor nervous disorders. But the benefits would be far greater; in particular, he would acquire a 'firmness of character' which would serve him well in life's struggles. ${ }^{36}$ Far from being set off course by a draining battle with instinct, the continent man would attain greater force. For Winfield Scott Hall, the young man had a clear choice: he could remain pure and emerge as 'hard-muscled, fiery-eyed, ambitious', or else he could indulge his desire, setting himself on a path to becoming a 'flabby-muscled, namby-pamby, cowardly mollycoddle lacking in initiative and will power' ${ }^{37}$ Continence, precisely by virtue of being harder for men than for women, was a crucial forge of manliness.

From endocrinology, then, the continence crusaders slipped into a language of masculine character and success. The strategies for successfully remaining continent would boost any man's chances of getting ahead. Doctors advised hard labour, mental training and a fixed goal in life. Their writings are filled with depictions of men who, thanks to their work ethic, determination and purpose, had little difficulty in maintaining sexual self-control. Dr James Peter Warbasse, editor of the New York State Journal of Medicine, reported a letter he had received from a patient who claimed to be suffering the effects of continence and asked for the best remedy. Warbasse's response was unbending. Self-control, discipline and a clear direction were all that any man required. 'The man with a determined principle', he responded, 'has clear sailing.' Those who lacked these qualities found the struggle much harder. 'The fellow who gets in trouble', Warbasse thundered, 'is the weak man, the one who vacillates.' ${ }^{38}$ Warbasse advised the patient to be decisive and confident, and, above all, to reject easy solutions. In taming sexual desire, the true man would propel himself to the lead in the wider contest of life.

\footnotetext{
${ }^{34}$ Edward L. Keyes Jr., 'The Sexual Necessity', Transactions of the American Society for Sanitary and Moral Prophylaxis, 1 (1906), 43-44.

${ }^{35}$ Exner, op. cit., (note 26), 18.

36 Exner, op. cit., (note 26), 8.

${ }^{37}$ Winfield Scott Hall, Youth and Its Problems: The Sex Life of a Man (Philadelphia: John C Winston, 1919), 116.

38 James Peter Warbasse, Medical Sociology: A Series of Observations Touching upon the Sociology of Health and the Relations of Medicine to Society (New York: D. Appleton and Company, 1909), 116.
} 


\section{Unhelpful and Unscientific: Opposition to Continence}

The apostles of continence hoped that a solid bloc of medical opinion would dispel any doubts about their message. On 7 June 1906, at the annual meeting of the American Medical Association, Morrow introduced a resolution that sexual continence is not injurious to health'. Any contrary doctrine, the resolution continued, was a 'menace to the physical and moral welfare of the individual and society'. ${ }^{39}$ No less than 370 doctors signed a statement circulated by Max J. Exner which affirmed that 'there is no evidence of its [continence] being inconsistent with the highest physical, mental and moral efficiency; and that it offers the only sure reliance for sexual health outside of marriage'. Any doctors expressing a contrary view were branded as charlatans, 'medical fakers', in Exner's terms, 'whose business depends on misrepresentation and deceit'. ${ }^{40}$

Dissent continued to come, however, and from men who could not be dismissed as quacks. In their influential textbook, University of Pennsylvania professors James William White and Edward Martin offered a careful criticism of the continence crusade. Abstinence achieved without any mental or physical struggle was probably harmless. But they made it clear that this was an unlikely scenario. More often, the chaste man would be caught between an obsessive fear of venereal disease and an equally strong desire for sexual relief, a state which was bound to produce a dangerous level of congestion. Sweeping statements in favour of the 'invariable harmlessness and even benefit of sexual continence', they concluded, were unscientific and easily disproved by clinical observation. ${ }^{41}$

Other doctors on the fringes of respectability denounced the continence campaign in much stronger terms. Prominent amongst these was Dr William J. Robinson. A physician who owned his own publishing house, Robinson edited a series of medical journals and published more than twenty books on sexual hygiene, eugenics and birth control. Robinson was incensed by what he saw as the moralising of the apostles of continence. The 'sexo-theologians', as he called them, had abandoned scientific argument in favour of a self-serving alliance with churches. Shorn of its moral dimension, the question of sexual necessity came down to health and happiness. Here, Robinson honed in on a trend in modern life which sociologists both recognised and lamented, the ever-lengthening delay in marriage, particularly for professional men. ${ }^{42}$ In a society where, because of extended periods of education, men remained bachelors much longer than their fathers, preaching abstinence was futile and dangerous. It might be possible for an adolescent male to remain chaste, Robinson argued, but older men had the right to better medical counsel. Nature, as they well knew, does not allow any 'function to lie fallow for years without meting out punishment'. ${ }^{43}$

Robinson might have been dismissed as a radical voice on the margins of the profession. But he nevertheless played a significant role in the debate by publicising the writings

39 'Official Minutes', Journal of the American Medical Association, 46 (1906), 1880.

${ }^{40}$ Exner, op. cit., (note 26), 14, 6.

${ }^{41}$ William J. White and Edward Martin, Genito-Urinary Surgery and Venereal Diseases (Philadelphia: J. B. Lippincott, 1910), 810-11.

${ }^{42}$ As the sociologist Charles A. Ellwood noted, "men in the professions do not think of marriage nowadays until thirty." Charles A. Ellwood, Sociology and Modern Social Problems (New York: American Book Company, 1919), 162.

43 William J. Robinson, Sex Knowledge for Men: Including a Program for Sex Education of the Boy (New York: Critic and Guide company, 1916), 79. Assessing Robinson's campaigns for contraception, Linda Gordon argues that 'Probably no doctor in America has been as influential in winning support for birth control and in defining its future development. Linda Gordon, The Moral Property of Women: A History of Birth Control Politics in America (Urbana: University of Illinois, 2002), 115. 
of a range of leading European authorities. Chief amongst these was Sigmund Freud. In 1915, Robinson published the first English translation of Freud's essay " "Civilized" Sexual Morality and Modern Nervous Illness'. ${ }^{44}$ In that essay, Freud blamed an overly strict sexual morality for the growing incidence of neurosis. This 'undue suppression' of sexual life was unsuitable for all but a small minority of ascetics; the majority would be troubled by impotence or forced to resort to what Freud considered to be infantile forms of sexual expression, such as masturbation. Some might be thrown off the normal path of development altogether. When the 'main stream' of libido was blocked, Freud argued, sexual energy would be pushed into the 'latent channel' of homosexuality. More fundamentally, Freud saw this unprecedented emphasis on sexual repression as hindering rather than helping the development of the male personality. It produced, he wrote, 'good weaklings', men who faced life's battles with resignation rather than with courage.

Freud had said as much on his lecture tour of the United States in 1909. Speaking at Clark University, he lamented the toll caused by excessive sexual repression. Some men might be able to draw a benefit from unfulfilled sexual desire through a process of sublimation, which Freud defined as the 'exchange of their sexual goal for one more remote and socially more valuable'. ${ }^{45}$ But sublimation could never absorb all of the 'suppressed libidinous excitation', which ought to find more direct forms of satisfaction. This was a lesson that modern society appeared to have forgotten. 'We ought not', he concluded, 'go so far as to fully neglect the original animal part of our nature', nor ignore the fact that individual happiness was a worthy and important ambition. ${ }^{46}$

This did not mean that the cure for neurosis was sex. The reason for this was set out by one of the pioneers of psychoanalysis in America, Abraham A. Brill. As Brill told the Eastern Medical Society of New York in 1911, sex in the Freudian sense 'not only embraces the coarse sexual, but also everything touching on and appertaining to it in the psychic and physical spheres' ${ }^{47}$ As a result, coitus alone might not resolve the sexual repression which underlay neurosis. But the potential for Freud's work to be used in support of the doctrine of sexual necessity became apparent at the same symposium. The young psychoanalyst Samuel A. Tannenbaum delivered a paper in which he identified sexual abstinence as a trigger for 'apprehension neurosis'. This was, according to Tannenbaum, by far the most common form of neurosis, constituting some 95\% of all cases which were diagnosed as neurasthenia. The 'purest cause' of the neurosis, he argued, was the 'frustrated excitement' experienced by couples when, out of fear of pregnancy or out of moral qualms, they engaged in foreplay but stopped short of intercourse. ${ }^{48}$ To avoid this, the gentleman engaged to a respectable lady would be well advised to seek relief with prostitutes; the doctor's duty in such cases was to provide him with 'proper instructions' on preventing venereal disease. Tannenbaum was careful to note that doctors should weigh such advice very carefully. But the 'conscientious physician', he wrote, 'will exercise his functions as a man and a humanitarian'. ${ }^{49}$

\footnotetext{
44 Sigmund Freud, 'Modern Sexual Morality and Modern Nervousness', American Journal of Urology and Sexology, 11, 10 (October 1915), 391-405.

45 Sigmund Freud, 'The Origin and Development of Psychoanalysis: Fifth Lecture', American Journal of Psychology 21 (1910), 217.

46 Ibid., 218. Nathan G. Hale, Freud and the Americans: The Beginnings of Psychoanalysis in the United States, 1876-1917 (New York: Oxford University Press, 1971), 11-13.

47 A.A. Brill, 'Freud's Theory of Compulsion Neurosis', American Medicine, 17 (1911), 647.

${ }^{48}$ Samuel A. Tannenbaum, 'Freud's 'Apprehension Neurosis”, American Medicine, 17 (1911), 640.

${ }^{49}$ Ibid., 643.
} 
In the pre-war period, continence crusaders largely managed to ward off the threat posed by Freudian theory. Many simply ignored his association between sexual repression and neurosis; others tried to turn it to their advantage by casting continence as a path to sublimation. Freud thought the capacity for sublimation to be limited. But in the hands of social hygienists, the process became far smoother, particularly amongst those races considered to be most evolved. Sublimation, in this view, was both a marker and a motor of racial superiority. In a pamphlet addressed to young men, William Lee Howard argued that the capacity to 'utilize primitive forces in stimulating intellectual processes' differentiated 'cultivated man from savage man'. ${ }^{50}$ This ability to neutralise the Freudian threat was aided by his limited public appeal in this period; it was not until the 1920s that Freud's works became bestsellers in the United States and his theory of sexual repression popularised.

\section{Changing Behaviour? Investigating the State University of Kentucky}

Perhaps the greater problem for the apostles of continence was the evidence that many young men were already acting along Freudian lines. In assessing medical views on sexuality, we need to move beyond prescriptive texts and assess the evidence of changes in behaviour or attitudes. Much of this evidence was collected by social hygienists themselves, and, as one investigation of college life showed, the results were often alarming.

College men were a particular point of concern for social hygienists. On the one hand, these were young men who, for reasons of race as well as class, were expected to lead the way in enshrining a new ethic of male chastity. Yet they were also in a difficult position. As Winfield Scott Hall noted, the 'conditions of college life', particularly the emphasis on athletics and field sports, created a 'body of most virile young men'. For the first time in their lives, they were unshackled from parental supervision. Their studies lasted well into their twenties, and many would then choose to spend several more years establishing themselves in professional life before even considering marriage. The upshot was a delay in sexual intercourse which would stretch far longer than that of any previous generation of men. How, Hall asked, under these 'unnatural circumstances', could college men lead a 'hygienic life'? ${ }^{51}$

Initial investigations suggested that many were failing to do so. In 1915, Max J. Exner published a study of the sexual habits of 948 college men. When asked about their sexual history, Exner found a large discrepancy between a group of students from Western colleges and another from the New York area. Among the former, no less than $81 \%$ had engaged in some form of sex. The highest proportion (61.5\%) admitted to masturbation. But $36 \%$ had experienced coitus. ${ }^{52}$ The figures from New York were much lower, but Exner discounted these on the basis that he had personally solicited the co-operation of the Western students and that their responses were therefore more likely to be truthful. While alarmed at these findings, Exner blamed a crude and unscientific sex education. When exposed to what he regarded as a comprehensive and hygienic program of instruction, the results were much more encouraging. Many of the students, he reported with satisfaction, had abandoned their belief in the sexual necessity and were now determined to lead continent lives.

50 William Lee Howard, Sex Problems Solved (New York: Edward J. Clode, 1915), 37.

${ }^{51}$ Hall, op. cit., (note 37), 131-2.

52 Max J. Exner, Problems and Principles of Sex Education: A Study of 948 College Men (New York: Association Press, 1915), 15-16. 
For Exner, education was the key to demolishing the belief in sexual necessity. But as an investigation of the State University of Kentucky suggested, many college students were being taught instead to sow their wild oats. The investigation began when the secretary of the YMCA at the university, Edward L. Hall, was forced to leave his post after rebuking several professors for their behaviour. This included inviting students into saloons, and circulating 'smutty stories' among the student body. ${ }^{53}$ In his role at the YMCA, Exner brought the matter to the attention of John D. Rockefeller Jr., the main financial supporter of the organisation which by now had superseded Morrow's ASSMP, the American Social Hygiene Association (ASHA). With Rockefeller's approval, the ASHA assigned the vice investigator George J. Kneeland to lead an inquiry.

An immediate target of the investigation was the president of the university, Henry S. Barker. The director of the ASHA, the New York lawyer James B. Reynolds, reported several damning statements made by Barker. One was that the red-light district around Megowan Street, just a short walk from the university campus, was a necessary outlet for the student body. Another was his view that gonorrhoea was no worse than a head cold. 'That suggests', Reynolds scathingly remarked, 'his general intelligence'. ${ }^{54}$ Evidence provided by the aggrieved YMCA secretary, Hall, supported these allegations. This included a letter from a Dr Young relating the 'smutty stories' told by Barker at a university banquet which had led all in the audience to 'hang their heads in shame'. ${ }^{5}$

The dire effect on student behaviour became clear in Kneeland's report. Over a series of nights in September and October 1915, Kneeland's agent recorded a large number of students in the red-light district. On 19 September, some 200 students were seen there. On 25 September, of the 75 students in the district, 38 went into a brothel. Bands of sophomores were seen hunting for freshmen in order to inflict on them one of the rituals of college life, the clipping of their hair. One student admitted that he lived in the brothel for the academic year; another was alleged to have taken a prostitute to a state football game. Perhaps even more alarmingly, the students reported that their professors were not only aware of such behaviour but tacitly approved. One revealed that the topic of prostitution had been discussed at college and that his professor had told them it was a 'necessary evil'. Another instructor had laughed when told that a group of freshmen had been found in Megowan Street. 'It don't take them long to get acquainted,' the instructor was reported to have said. That staff might be ignorant of such behaviour was mocked by another student, who noted that the brothel he frequented was only a two-minute walk from the administration building.

Reynolds sent the report to each member of the Executive Committee of the University's Board of Trustees, calling on them to 'remove the present flagrant temptations to student immorality'. He threatened to make the report public if no action were taken. ${ }^{56}$ In January 1916, Reynolds travelled to Lexington and met with Barker as well as members of the board. By then a newly elected City Commission had closed the red-light district near the campus. On 22 January, the trustees resolved that any students found in brothels by the

\footnotetext{
53 'A Brief Review of the Facts Leading up to Opposition Against E.L. Hall, Secretary of the State University YMCA', Bureau of Social Research Records, Series 3, subseries 2, Folder 184 'Lexington Investigation, 1915'.

${ }^{54}$ James B. Reynolds to Abraham Flexner, May 10, 1915, Bureau of Social Research Records, Series 3, subseries 2, Folder 184 'Lexington Investigation, 1915'.

55 Edward L. Hall to James B. Reynolds, May 6, 1915, Bureau of Social Research Records, Series 3, subseries 2, Folder 184 'Lexington Investigation, 1915'.

${ }^{56}$ Letter dated November 22, 1915, Bureau of Social Research Records, Series 3, subseries 2, Folder 184 'Lexington Investigation, 1915'.
} 
police should be handed to the university to be disciplined. In a letter to the ASHA, Barker cited this as proof of his determination to reform behaviour. But Barker also came to the defence of his students. There was no body of state students in the United States 'who have higher moral ideals and live up to those ideals more thoroughly'. Barker's confidence was based in part upon his belief that young men who engaged in illicit sex would lack the energy and character to succeed. The courses at Kentucky were so demanding, he reminded the ASHA, that any student who 'debauches himself' had little hope of completing the work that was required in the freshman year. ${ }^{57}$

\section{Risks and Opportunities: The Wartime Experience}

When the United States entered World War I, social hygienists saw a great risk as well as a great opportunity. On the one hand, the recent record of the army was not encouraging. During the incursion into Mexico in 1916, several officers had set up regulated brothels for the benefit of their soldiers; one, Major-General John J. Pershing, was subsequently appointed Commander of the American Expeditionary Force (AEF) to France. American soldiers would also be exposed to the sexual climate of France, a nation which many hygienists saw as steeped in promiscuity. The demands of military efficiency over moral purity, combined with the exposure to Old World corruption, threatened to undo all the campaigning for continence since the turn of the century. Yet here was a chance to demolish once and for all the belief that a continent man could not be an effective fighter and to make the soldier a model of sexual discipline which all men could emulate. World War I promised a victory over the doctrine of sexual necessity.

On one level, these expectations were more than met. As Allen Brandt and Nancy K. Bristow have detailed, the military command and federal government together set out to make the AEF the most sexually disciplined army the world had ever seen. Just two weeks after the declaration of war, the General Medical Board of the Council of National Defense issued a resolution in favour of continence. Educational pamphlets, lectures and, for the first time, films all hammered home the message that the surest means of avoiding venereal disease was continence and that the soldier would benefit from the energy and force which sexual restraint provided. The film, 'Fit to Fight', showed the contrasting fates of five recruits - Billy, Jack, Kid, Hank and Chick. All receive stern warnings of the dangers of venereal disease from the base commander, but Jack, Hank and Chick visit a brothel regardless. The film ends with these three, described as 'useless slackers', being treated in hospital for venereal disease. Only Billy and Kid are free to pursue the great adventure in France. The standing of the pure Billy is further enhanced after he knocks out Kid in a fight, thus proving to his fellow soldiers that clean living made a man stronger.

Such campaigns received the full support of the AEF command. Major Hugh H. Young, the director of the Division of Urology in the AEF, convinced Pershing of the threat posed by venereal disease to the war effort, and the result was a series of directives which combined persuasion with coercion. General Order 34, issued on 9 September 1917, dictated in its first clause that 'high moral standards of living' were expected of the AEF. Bulletin 54, issued on 7 August 1918, described continence as the 'plain duty' of the American soldier, denied that sexual intercourse was necessary for health and stressed that such discipline was entirely realistic. Commanding officers were instructed to enforce

\footnotetext{
${ }^{57}$ Henry V. Barker to James Bronson Reynolds, February 18, 1916, Bureau of Social Research Records, Series 3 ,
} subseries 2, Folder 184 'Lexington Investigation, 1915'. 
this message amongst troops as well as to provide 'instruction, work, drill, athletics and amusements'.58

The overriding military goal of keeping soldiers fit, however, undercut these directives. At the same time as it urged soldiers to be abstinent, the military command, with the support of the medical corps, instituted a program of medical prophylaxis which aimed to mitigate the consequences of illicit intercourse. All soldiers who engaged in intercourse were ordered to report to prophylaxis stations. The treatment, which consisted of washing the genital organs, injecting an antiseptic solution into the penis and applying a mercurybased ointment called calomel, was considered by the Office of the Chief Surgeon to be nearly one hundred per cent effective in preventing venereal infection if administered within three hours of contact. In the context of the army's drive to maximise its fighting resources, most medical men thought prophylaxis an acceptable compromise. 'If by some unfortunate situation', Winfield Scott Hall wrote, a soldier had 'made a fool of himself', prophylaxis was an appropriate fallback. But such measures, Hall hastened to add, were no aspersion on the moral purity of the AEF, the "cleanest, finest army in all the history of the world'. 59

Where the army was not prepared to compromise was on the question of regulated prostitution. French authorities urged the American command to follow their example by establishing a system of medical inspection of prostitutes in approved brothels. In their view, this was the only realistic way to prevent soldiers contracting disease. The divisions that ensued when the Americans refused to comply are recorded in the papers of Edward L. Keyes Jr, the pre-war campaigner for continence who arrived in France as a major in the Medical Reserve Corps in 1917. As assistant director of the Division of Urology, Keyes participated in several meetings on the question of venereal disease. While agreement on some points was reached, a gulf remained on the question of army brothels, and Keyes was sure he knew why. The 'average Frenchman', he reported to the War Department, 'is totally unable to comprehend or sympathize with any code of morals that issues from the maxim that sexual activity is not imperative' ${ }^{60}$ This was what underlay the French army's belief in regulation and its dismissive attitude to the continence message. The AEF, in contrast, was at one with its citizenry in believing that the 'so-called sexual necessity of man is an absolute, not a relative thing' and, as such, subject to control. ${ }^{61}$ The Americans would stick to continence backed up by prophylaxis.

Keyes was aware that not all army doctors were of the same view. Many regimental surgeons, he recorded in his reports, had little or no interest in venereal disease and thought the continence campaign foolhardy. At a 1919 conference held under the auspices of the army chaplain, several participants lamented that the 'attitude of many members of the Medical Corps' as well as 'many members of the medical profession in civilian life' continued to favour the doctrine of sexual necessity. ${ }^{62}$ But research undertaken by

\footnotetext{
${ }^{58}$ For an account of the army's measures by Young, see Hugh Hampton Young, 'Preventive Medicine As Applied to Venereal and Skin Diseases', Transactions of the Section on Genito-Urinary Diseases of the American Medical Association (1919): 202-261.

${ }^{59}$ Hall, op. cit., (note 37), 24-5.

60 'Report to Major William S Snow, February 18, 1918', Box 7, Folder 19, Edward Loughborough Keyes Jr Papers, Georgetown University Special Collections Research Center (Washington DC).

61 'The Social Basis of the Campaign Against Venereal Diseases in the AEF', Box 7, Folder 17, Edward Loughborough Keyes Jr Papers, Georgetown University Special Collections Research Center (Washington DC). 62 'Extracts from Memorandum of Conference to Consider Venereal Situation, February 27, 1919', RG120, NM92 Entry 2065, Box 5170, National Archives (College Park).
} 
hygienists themselves suggested that the real problem lay among the troops. A 1919 report to the Clinical Chief of the Genito-Urinary Section of the Medical Department, Colonel George Walker, from two officers in his division, William D. Jack and Herbert Foster, showed that some $40 \%$ of men on leave in Aix-les-Bains engaged in intercourse. ${ }^{63}$ This might have been put down to the relaxation of discipline after the Armistice. But two comprehensive reports which surveyed the period from 1917 onwards suggested that continence was far from the rule in the AEF. One, by Colonel Walker himself, found that $71 \%$ of all American soldiers had engaged in sexual intercourse during their posting in France. ${ }^{64}$ A similar picture emerged from an even more comprehensive survey. In 1919, Dr Percy M. Ashburn published a study of the sexual behaviour of 13,648 AEF soldiers. Ashburn asked the men directly if they had engaged in sexual intercourse during their period of service, a period which averaged ten months. He found that only $34 \%$ had abstained entirely from sex in that time. ${ }^{65}$

In public at least, members of the medical corps continued to insist that the campaign for continence had been a stunning success. Walker argued that given all the obstacles - the entrenched belief in sexual necessity amongst soldiers and many officers, the distance from home, the climate of sexual corruption in France, the difficulty of monitoring the activities of soldiers on leave - the level of sexual restraint amongst the AEF was an extraordinary achievement. He went on to argue that the AEF experience had proven to be uplifting rather than degrading. The majority of recruits, as Walker argued, had been raised with the belief that sex was 'manly and necessary'. When informed that this was not true, and when given the opportunity to apply the lesson first-hand, their sexual attitudes and behaviour had quickly changed. ${ }^{66}$ Now it was time, Walker concluded, to bring the lessons learnt in the trenches back to the home front.

\section{When You Go Home: Sexual Necessity After World War I}

By war's end, and despite all the evidence to the contrary, social hygienists clung to the hope that a great turning point was at hand. Thousands of disciplined men, alive to the virtues of sexual discipline, would come home and inaugurate a new era in the history of male sexual behaviour. A pamphlet entitled 'When you go home' urged returning soldiers to set higher standards of chastity for the entire community. The army, the pamphlet boasted, was 'ten times cleaner than the country'. Soldiers now knew that it was not necessary to go with women to keep well' and not true that a 'man's sex organs ... grow weak if they are not used'. ${ }^{67}$ Having defeated Germany, the soldiers' next task was to safeguard future generations of Americans from the scourge of venereal disease. Echoing President Woodrow Wilson's call for a new era of democracy and freedom, the pamphlet urged returning soldiers to 'make the world safe for posterity'. ${ }^{6}$

\footnotetext{
63 'Weekly report Feb 8 - Feb 16 1919', RG120, NM92 Entry 2065, Box 5170, National Archives (College Park).

${ }^{64}$ George Walker, Venereal Disease in the American Expeditionary Forces (Baltimore: Medical Standard Book Company, 1922), 101.

65 Percy M. Ashburn, 'Factors Making for a Low Venereal Record in the American Expeditionary Forces', Journal of the American Medical Association, 73, 24 (1919), 1825.

66 Walker, op. cit., (note 64), 45.

${ }^{67}$ When You Go Home - Take This Book With You (US Public Health Service, Division of Venereal Diseases), 13. For an example of a poster with the same message, see the following digital collection at the Library of Congress, http://www.loc.gov/pictures/collection/wwipos/item/00652170/.

${ }^{68}$ Ibid., 6.
} 
These hopes, however, were soon disappointed. A number of studies suggested that amongst the civilian population, the belief in male sexual necessity was as tenacious as ever. In 1920, a federal government agency, the Interdepartmental Social Hygiene Board, conducted a study of the effectiveness of sex education films. In particular, the study examined the effect of a film entitled 'Fit to Win', which had been adapted from its military equivalent, 'Fit to Fight'. The study came to two conclusions, both of which were disheartening for advocates of male continence. The first was that the belief in sexual necessity remained widespread. Questioned before seeing the film, no less than $51 \%$ of one sample group of men thought that sex was necessary to health, with only $26 \%$ believing it to be unnecessary. ${ }^{69}$ Even worse, follow-up fieldwork suggested that the message of continence at the heart of the film had little lasting effect. The authors recorded what they saw as a typical response: 'I saw the picture about eight months ago and thought it was a mighty good thing. But another fellow and I had a date for that night and we went out with a couple of girls and had a big night, anyway. ${ }^{70}$

At the same time, medical opinion was becoming even more fractured. This was clear in a 1920 survey of selected members of the American Psychopathological Association as well as the Association of Genito-Urinary Surgeons. One question asked about the frequency of mental disturbances due to abstinence; so variable were the replies that the survey authors published them all in full. Many responded that such disturbances were infrequent, or that abstinence was rarely in itself the cause. But others saw a clear linkage. One of the first and most active Freudians in the United States, Smith Ely Jelliffe, described mild neurotic disturbance as 'universal'. Ernest Jones, the co-founder of the American Psychoanalytic Association, simply answered 'very'. The opinion of the surgeons was also mixed. Most replied 'rare' or 'infrequent'. But Hugh Cabot, professor of surgery at the University of Michigan, attested that he had seen many cases of abstinence 'causing grave interference with work' ${ }^{71}$

When asked if doctors should recommend intercourse to the unmarried under certain circumstances, opinion was again mixed. Very few were prepared to defend such a controversial practice in public. But the basis for their reticence was often social convention rather than physiology. The renowned neurologist and psychiatrist Abraham Myerson described continence as harmful to the individual but beneficial to society. The patient was left, he conceded, on 'the horns of a dilemma which I cannot offhand solve'. One doctor cited the AEF as proof that absolute continence should always be recommended. On the other hand, Dr H.W. Frink, a clinical neurologist at Cornell Medical College, was adamant that a strict abstinence was worse than an intelligently taken indulgence'. ${ }^{72}$

These differences, as well as the growing impact of Freudians on the debate, were given a public airing at the 1921 All-America Conference on Venereal Diseases in Washington DC. The meeting was the first in a series of regional conferences designed to review and refine practical measures for combating venereal disease and brought together some 450 experts from across the Americas. Among the questions for discussion at the conference

${ }^{69}$ Karl S. Lashley and John B. Watson, A Psychological Study of Motion Pictures in Relation to Venereal Disease Campaigns (Washington DC: United States Interdepartmental Social Hygiene Board, 1922), 23.

${ }^{70}$ Ibid., 61.

71 John B. Watson and Karl S. Lashley, 'A Consensus of Medical Opinion Upon Questions Relating to Sex Education and Venereal Disease Campaigns', Mental Hygiene 4, 4 (1920), $794-8$.

${ }^{72}$ Ibid., 800-4. 
were the effectiveness of tests and treatments for syphilis, laws governing the identification and treatment of patients, the establishment of specialised clinics, and the benefit of sex education. But the question of continence generated the most heated discussion. Many of the physicians labelled absolute sexual abstinence as 'not a physiologic state in a sexually normal adult'. Freudians intervened as well, arguing that the entire repression of the sex instinct might, if not channelled into socially useful activities, be psychologically damaging. After much debate, the conference agreed on a compromise resolution which, whilst avoiding any sweeping statements in favour of sexual abstinence, affirmed that its negative effects were outweighed by the risks associated with promiscuity. ${ }^{73}$

\section{Conclusion}

The campaign to demolish the doctrine of male sexual necessity was a testament to the ambition and spirit of the Progressive era. In a manner akin to efforts to eradicate dysentery or tuberculosis, the apostles of continence set out not merely to defeat venereal disease but also to bring about a revolutionary change in individual behaviour. The nation would never be cleansed from the stain of syphilis and gonorrhoea until men willingly embraced a sanitary and rational approach to sex with chastity at its core. Central to their vision was a particular conception of masculinity. In the midst of a widespread panic over the emasculating effects of modern civilisation, social hygienists offered an alternative to physical combat or outdoor activities. Men could regain their vigour, their sense of power and self-control, by steeling themselves against one of the most formidable opponents of all, sexual desire. In so doing, they could gain mastery over themselves and over others as well.

The continence crusade thus shows the importance of gender within medical discourse. In seeking to convince men that sex was not necessary, doctors appealed to notions of true masculinity as much as physiology. But their campaign reveals as well the divided, unsettled nature of medical opinion. While at first glance there seemed near unanimity within the profession, significant and growing strains of dissent were never far from the surface. The international dimension was also important. On one hand, American doctors liked to draw a contrast with attitudes and practices in the Old World. Over there, they argued, physicians and patients alike were convinced that sex was imperative. The clashes with French authorities during World War I were further proof of a transatlantic divide. Yet social hygienists drew support and inspiration from like-minded reformers abroad. The interplay between the national and the transnational shaped the American debate in powerful and often contradictory ways.

Finally, this campaign shows the need to assess impact. The apostles of continence were never content merely to launch exhortations in the manner of clergymen. Instead, they sought to measure the evidence of change in attitudes and, more importantly, in behaviour. At times, the results seemed comforting. But by the early 1920s it was difficult to see any great success. The growing popularity of Freudian theory pointed to major challenges ahead. Worse, even after more than a decade of agitation and organisation, the target audience showed little sign of having absorbed the message. For all their zeal, the apostles of continence never managed to win over large numbers of men who remained convinced that sex was not just pleasurable but, for reasons of health and efficiency as well as their own sense of manhood, necessary.

73 'All-America Conference on Venereal Diseases: Report on the Proceedings and the Resolutions of the General Conference Committee', Public Health Reports 36, 28 (1921), 1628-30. 